\begin{tabular}{|c|c|c|c|c|c|c|}
\hline \multirow{4}{*}{ Impact Factor: } & ISRA (India) & $=3.117$ & SIS (USA) & $=0.912$ & ICV (Poland) & $=6.630$ \\
\hline & ISI (Dubai, UAE & $=\mathbf{0 . 8 2 9}$ & РИНЦ (Russia & $=0.156$ & PIF (India) & $=1.940$ \\
\hline & GIF (Australia) & $=0.564$ & ESJI (KZ) & $=\mathbf{5 . 0 1 5}$ & IBI (India) & $=4.260$ \\
\hline & JIF & $=1.500$ & SJIF (Morocco & $=5.667$ & OAJI (USA) & $=0.350$ \\
\hline
\end{tabular}

\begin{tabular}{|c|c|}
\hline \multicolumn{2}{|c|}{$\begin{array}{l}\text { SOI: } \underline{1.1 / \mathrm{TAS}} \text { DOI: } \frac{10.15863 / \mathrm{TAS}}{\text { International Scientific Journal }} \\
\text { Theoretical \& Applied Science }\end{array}$} \\
\hline p-ISSN: 2308-4944 (print) & e-ISSN: 2409-0085 (online) \\
\hline Year: 2019 & Volume: 69 \\
\hline Published: 30.01 .2019 & http://T-Science.org \\
\hline
\end{tabular}

SECTION 31. Economic research, finance, innovation, risk management.
QR - Issue

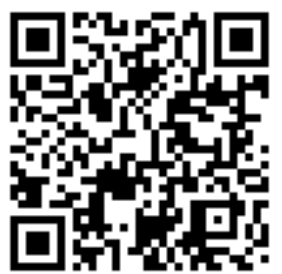

QR - Article

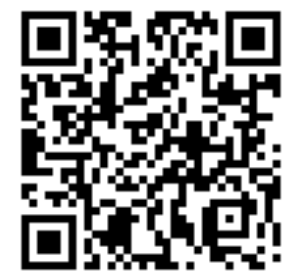

Iroda Akbarovna Bakiyeva

Ph.D, docent,

Tashkent state university of economics

Nazira Iskandarovna Radjabova

Senior teacher,

Tashkent state university of economics

\title{
WAYS OF INCREASING LABOR PRODUCTIVITY IN TEXTILES
}

Abstract: This article discusses issues of increasing labor productivity in textile enterprises, the author presents the periodization of productivity concepts. In addition, in the process of the study, an assessment of labor productivity was carried out using the example of a textile enterprise conditionally called " $N$ ". At the end, conclusions are summarized and drawn, and scientific recommendations for improving labor efficiency are proposed.

Key words: labor, textile enterprises, labor resources, labor efficiency, labor productivity, incentive, bonus.

Language: English

Citation: Bakiyeva, I. A., \& Radjabova, N. I. (2019). Ways of increasing labor productivity in textiles. ISJ Theoretical \& Applied Science, 01 (69), 316-320.

Soi: http://s-o-i.org/1.1/TAS-01-69-44 Doi: crossef https://dx.doi.org/10.15863/TAS.2019.01.69.44

\section{Introduction}

The importance of efficient use of labor is beyond doubt, since it directly affects the activity of the enterprise as a whole, the rational provision of the production process, and the improvement of the quality and competitiveness of products. Under constantly changing environmental conditions, it is quite difficult for enterprises to maintain a high level of operational efficiency and labor productivity. Enterprises have to constantly optimize and improve production processes in order to be able to succeed in competition. Labor productivity is directly dependent on each individual employee of the enterprise. At the same time, wages and their predicted growth play a decisive role.

\section{Literature review}

The issues of increasing labor productivity have always been and remain at the center of attention of economics. The most important aspects of the content of labor productivity, the factors and directions of its growth, the methodological principles of measurement and planning are defined in the works of Zubkova A.F., Slezinger G.E. [1], Silantyev N.A., Malinovsky V.R. [2], Scott Sink, D. [3], Uzdemir A.P. [4], Ehrenberg R.J., Smith R.S. [5], Tursunov B.O. [11-13] and others. In the sectoral economic literature in scientific and practical terms, the problems of increasing labor productivity were developed in the works of Fisher, S., Dornbusch, P., Schmalenzi, P. [6], Yakovlev R.A. [10] A.N. Zhigalov, N.V. Romanova, T.F. Ryabova and others. However, it must be noted that, for all the importance and complexity of the problem of increasing productivity, many of its aspects are not studied deeply. These include methodological and practical issues of increasing the volume of finished product production, as well as planning the number of employees and determining the influence of the main directions of scientific and technological progress. Requires a comprehensive analysis and classification of factors of productivity growth, including socio-economic.

\section{Analysis and results}

Despite the existing diversity of approaches to understanding the essence of efficiency and productivity of labor, there is currently no single concept defining the main factors and assumptions of the theory of labor productivity. Changes in internal and external conditions are an inevitable reason for the further development of approaches to productivity. Over the past decades, several approaches have been formed that define the essence of labor productivity by such authors as A. Smith, F. Taylor [9], D.S. Sink, and others. The periodization 


\begin{tabular}{|c|c|c|c|c|c|c|}
\hline \multirow{4}{*}{ Impact Factor: } & ISRA (India) & $=3.117$ & SIS (USA) & $=0.912$ & ICV (Poland) & $=6.630$ \\
\hline & ISI (Dubai, UAE & $=0.829$ & РИНЦ (Russia) & $=0.156$ & PIF (India) & $=1.940$ \\
\hline & GIF (Australia) & $=0.564$ & ESJI (KZ) & $=\mathbf{5 . 0 1 5}$ & IBI (India) & $=4.260$ \\
\hline & JIF & $=1.500$ & SJIF (Morocco) & $=5.667$ & OAJI (USA) & $=0.350$ \\
\hline
\end{tabular}

of the concepts of labor productivity management is presented in Table. 1.

Table 1. Periodization of concepts of productivity management [12]

\begin{tabular}{|c|c|c|c|}
\hline Levels & Period & Economic school & Authors \\
\hline 1-step & XVII-IX ages. & Early political economy & A. Smith, D. Ricardo \\
\hline 2- step & 1885-1920-s yy. & $\begin{array}{l}\begin{array}{l}\text { Scientific } \\
\text { Management }\end{array} \\
\end{array}$ & F. Taylor \\
\hline 3- step & 1920-1950 уу. & $\begin{array}{l}\text { Administrative School of } \\
\text { Management }\end{array}$ & G. Ford, A. Fayol, L. Weber \\
\hline 4- step & 1930-1950 уу. & School of Human Relations & $\begin{array}{l}\text { E. Mayo, A. Maslow, K. } \\
\text { Argyris }\end{array}$ \\
\hline
\end{tabular}

The modern understanding of productivity in foreign countries is characterized by the absolutization of labor and the labor factor of production, that is, only labor creates value, including surplus. The foreign approach to the problem lies in the fact that productivity is the sum of output per unit of input factors of production. For Japan, productivity is the pursuit of progress, the gradual improvement and adaptation of economic activity to changing conditions. The key point of the concept of productivity is a person-centered and social orientation. Thus, in the world, productivity is commonly understood as the effective use of all types of resources in the production of products.

The difference of these concepts can be traced in the following formulations: "The indicator of the efficiency of the labor process is expressed by the ratio of production results to the corresponding costs of directly living labor" [7]. Productivity - "the ratio of the number of products produced by this system for a given period of time to the amount of resources consumed for the creation or production of these products for the same period" [8].

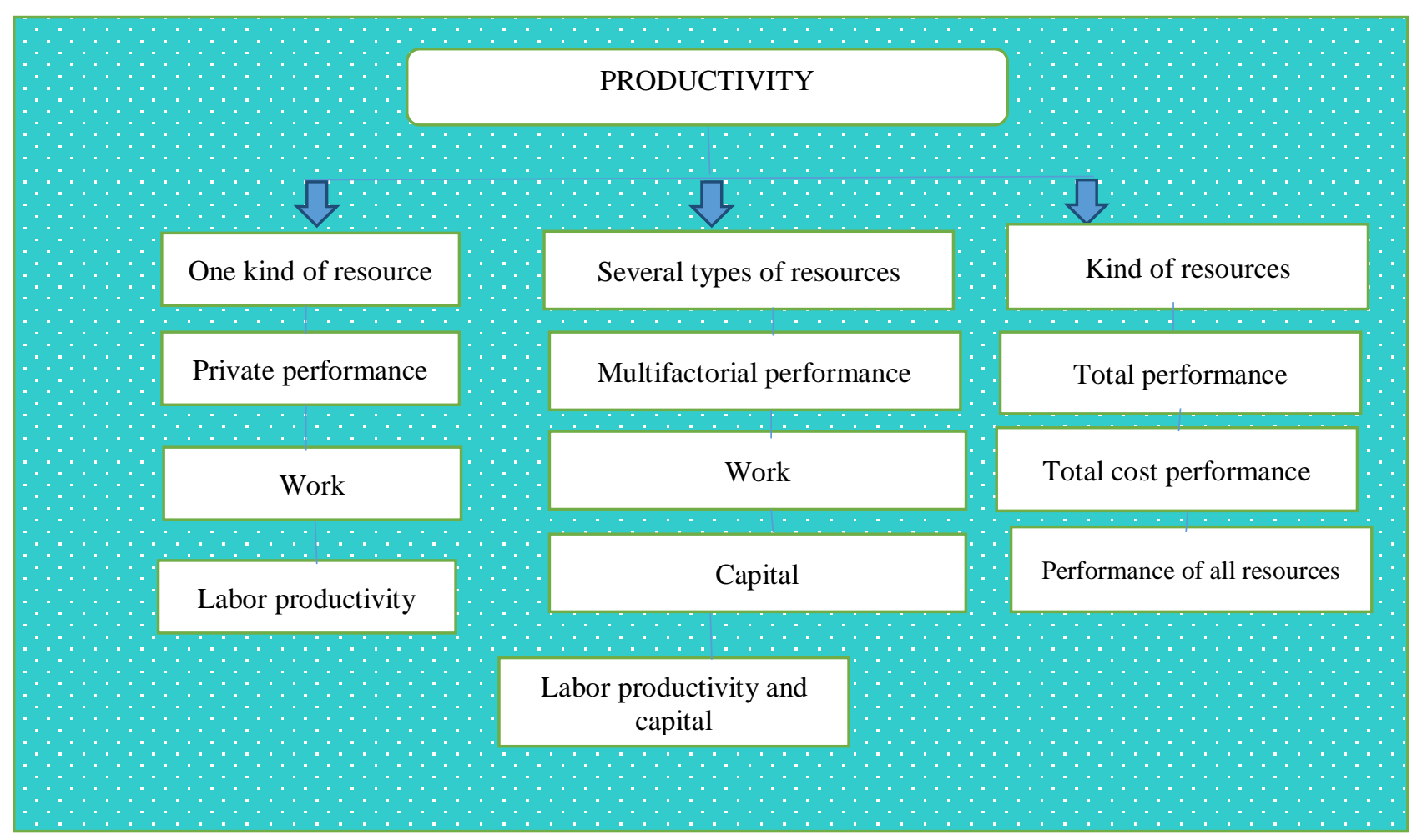

Fig. 1. Performance Indicators [12]

Depending on the types of resources taken into account, different indicators are used: labor productivity, labor productivity and capital, and productivity of all resources. 


\begin{tabular}{|c|c|c|c|c|c|c|}
\hline \multirow{4}{*}{ Impact Factor: } & ISRA (India) & $=3.117$ & SIS (USA) & $=0.912$ & ICV (Poland) & $=6.630$ \\
\hline & ISI (Dubai, UAE & $=0.829$ & РИНЦ (Russia & $=0.156$ & PIF (India) & $=1.940$ \\
\hline & GIF (Australia) & $=0.564$ & ESJI (KZ) & $=5.015$ & IBI (India) & $=4.260$ \\
\hline & JIF & $=1.500$ & SJIF (Morocce & $=5.667$ & OAJI (USA) & $=0.350$ \\
\hline
\end{tabular}

Depending on the scale of production, its results can be expressed as gross domestic product - in the whole country, the gross product of the subjects or the volume of the company's output. At the same time, to characterize the efficiency of the produced or labor process, the dynamics are important in comparison with another similar value, taken as the basis for comparison. Such a comparison makes it possible to determine the degree of success of the activity and the degree of use of labor resources. In addition, the growth of labor productivity provides a solution to other economic problems of the enterprise, such as reducing production costs, increasing production volumes, increasing corporate culture, consolidating staff to fulfill the mission of the enterprise, improving labor safety, obtaining additional profits necessary for enterprise development, increasing wages wages of employees, social development of the team.
Ensuring increased efficiency and productivity should be based on an assessment of the labor resources of the enterprise, including an analysis of the movement of employees, an analysis of working time, an analysis of labor productivity, as well as an assessment of the employee motivation system. We will assess the use of labor on the example of enterprise "N", the first stage of which is the analysis of the dynamics of the number of employees. Thus, we can see that during the analyzed period, a significant change in the number of personnel did not happen. The rational use of the labor resources of the enterprise is an indispensable condition that ensures the continuity of the production process and the successful implementation of production plans. Analysis of the use of the fund of working time of the enterprise is presented in table. 2.

Table 2. Analysis of the use of the fund of working time of the enterprise "N"

\begin{tabular}{|c|c|c|c|c|c|}
\hline & \multirow[t]{2}{*}{2017 year } & \multicolumn{2}{|c|}{2018 year } & \multicolumn{2}{|c|}{ Deviation } \\
\hline & & Plan & Fact & $\begin{array}{c}2017 \text { year to } \\
2016 \text { year }\end{array}$ & $\begin{array}{c}\text { To plan } 2017 \\
\text { year }\end{array}$ \\
\hline $\begin{array}{lr}\text { Number } & \text { of } \\
\text { employees } & \text { (annual } \\
\text { average) } & \\
\end{array}$ & 322 & 325 & 321 & -1 & +3 \\
\hline $\begin{array}{l}\text { Time worked by one } \\
\text { employee }\end{array}$ & 2080 & 2088 & 2016 & -64 & +8 \\
\hline $\begin{array}{l}\text { The duration of the } \\
\text { working day } \\
\text { (average, h) }\end{array}$ & 8 & 8 & 8 & 0 & 0 \\
\hline $\begin{array}{l}\text { Fund of working } \\
\text { time, (person / h) }\end{array}$ & 669760 & 678600 & 647136 & -22624 & +8840 \\
\hline
\end{tabular}

Source: author`s elaboration.

Evaluation of the use of working time shows that the company has unused reserves; for example, in 2015 there is a reduction in working hours compared to both 2014 and planned indicators.
The efficiency of the use of labor resources is reflected in the level of labor productivity, presented in Table. 3

Table 3. Analysis of the use of labor productivity of the enterprise " $N$ " in 2016-2018

\begin{tabular}{|c|c|c|c|c|c|}
\hline Indicator & $\mathbf{2 0 1 6}$ & $\mathbf{2 0 1 7}$ & $\mathbf{2 0 1 8}$ & \multicolumn{2}{|c|}{ Deviation } \\
\cline { 2 - 5 } & & & \multicolumn{2}{c|}{$\begin{array}{c}\text { Deviation in } \\
\mathbf{2 0 1 7} \text { to 2016 } \\
\text { Deviation in }\end{array}$} & $\begin{array}{c}\mathbf{2 0 1 8} \text { to 2017 } \\
\mathbf{( + )}\end{array}$ \\
\hline $\begin{array}{c}\text { The volume of } \\
\text { production, } \\
\text { thousand sum }\end{array}$ & 1236854 & 1325747 & 1418900 & 88893 & 93153 \\
\hline $\begin{array}{c}\text { Average number } \\
\text { of employees }\end{array}$ & 320 & 322 & 321 & 1 & -2 \\
\hline $\begin{array}{c}\text { Average daily } \\
\text { output of workers, } \\
\text { thousand sum }\end{array}$ & 322,1 & 343,1 & 368,4 & 46,3 & 46,3 \\
\hline Average annual & 3865,1 & 4117,2 & 4420,2 & 555,1 & 303,0 \\
\hline
\end{tabular}




\begin{tabular}{|c|c|c|c|c|c|c|}
\hline \multirow{4}{*}{ Impact Factor: } & ISRA (India) & $=3.117$ & SIS (USA) & $=0.912$ & ICV (Poland) & $=6.630$ \\
\hline & ISI (Dubai, UAE & $=0.829$ & РИНЦ (Russia) & $=0.156$ & PIF (India) & $=1.940$ \\
\hline & GIF (Australia) & $=0.564$ & ESJI (KZ) & $=\mathbf{5 . 0 1 5}$ & IBI (India) & $=4.260$ \\
\hline & JIF & $=1.500$ & SJIF (Morocco) & $=5.667$ & OAJI (USA) & $=0.350$ \\
\hline
\end{tabular}

\begin{tabular}{|c|l|l|l|l|}
\hline $\begin{array}{c}\text { output of workers, } \\
\text { thousand sum }\end{array}$ & & & & \\
\hline
\end{tabular}

Source: author`s elaboration.

Evaluation of changes in labor productivity leads to the conclusion that the decrease in the average annual output of the company's employees was influenced by two factors: an increase in the proportion of workers in the total number of industrial and production personnel, as well as a decrease in the number of days worked. Due to the first factor, the average annual output increased by 41.96 thousand UZS, and due to the second decreased by 52.48 thousand UZS.

Thus, the company needs to pay attention to finding reserves for improving labor efficiency, which can be divided into two groups: the first one includes extensive reserves, i.e., an increase in production volume due to an increase in the number of employees and the number of machines and mechanisms they use. The second group includes intensive reserves of increase in labor efficiency. The growth of labor productivity by an extensive method will lead to a growth of the unit structure, its uncontrollability and an increase in the cost of production due to an increase in wages and salaries, therefore in modern conditions it is considered expedient to use reserves of labor efficiency of an intensive nature. A set of measures aimed at improving the efficiency of personnel work, as one of the stages of achieving the ultimate goal of an enterprise, should include an effective personnel motivation system aimed at increasing the share of employees with value-based work motivation; structuring staff incentives; improving the organization of labor and the speed of management decisions.

As with any activity, work on improving productivity requires management: setting goals, how to achieve them, organizing work on its implementation, monitoring and accounting. [12]

Labor productivity management is a process aimed at increasing productivity. The main work to increase productivity is aimed at both the implementation of internal reserves of its growth and the use of the positive influence of factors that increase labor productivity, and this work should not be viewed as a one-off act, but as a continuous process contributing to the achievement of the main goal of the enterprise. Among the factors of a positive impact on productivity, motivation of labor activity can be distinguished. The role of motivation in increasing productivity can be represented in Fig. 3.

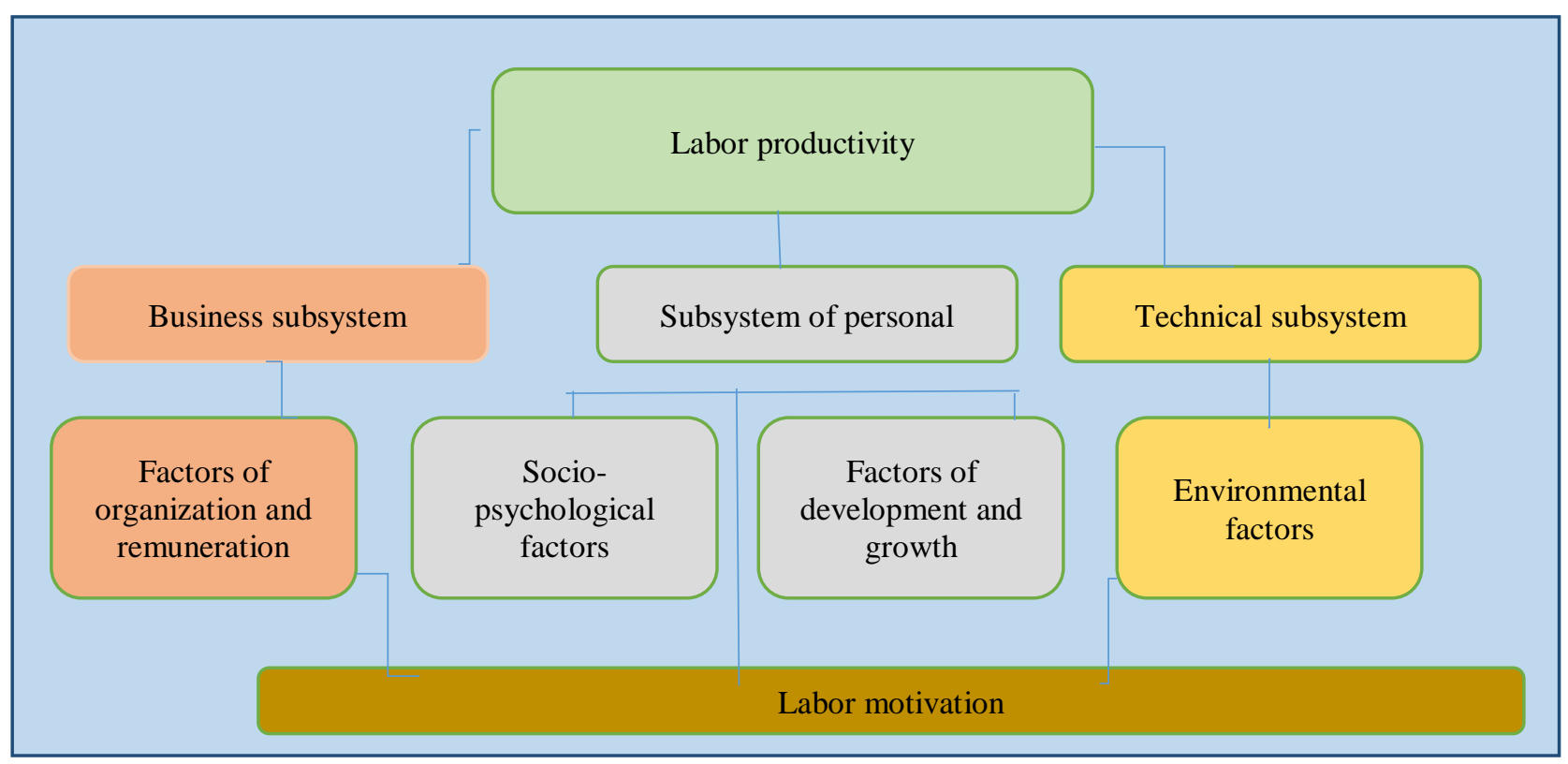

Fig. 3. Labor motivation in productivity system. [12]

A significant potential for increasing labor productivity lies in the system of labor motivation. So, for example, the division of wages into the main payable depending on the position held, and the remuneration determined by the results of the individual contribution of employees, contributes to a more objective assessment of the quantity and quality of labor of staff.

\section{Conclusion}

The employee remuneration structure may include from one to fifteen elements. As a rule, the 


\begin{tabular}{|c|c|c|c|c|c|c|}
\hline \multirow{4}{*}{ Impact Factor: } & ISRA (India) & $=3.117$ & SIS (USA) & $=0.912$ & ICV (Poland) & $=6.630$ \\
\hline & ISI (Dubai, UAE & $=0.829$ & РИНЦ (Russia) & $=0.156$ & PIF (India) & $=1.940$ \\
\hline & GIF (Australia) & $=0.564$ & ESJI (KZ) & $=\mathbf{5 . 0 1 5}$ & IBI (India) & $=4.260$ \\
\hline & JIF & $=1.500$ & SJIF (Morocco) & $=5.667$ & OAJI (USA) & $=0.350$ \\
\hline
\end{tabular}

more such components, the higher the level of management culture of the enterprise.

It is most effective to build a system of a permanent part of the remuneration on the basis of grading This allows in a short time with high accuracy to assess jobs and make their rating in order of importance for the final result.
The main purpose of the award is to encourage the workforce to achieve a specific result. The economic approach of material incentives is to establish a number of indicators on which the provision on bonuses.

\section{References:}

1. Zubkova, A. F., \& Slezinger, G. E. (1997). Organization of labor regulation in enterprises. M.: Informtsentr-Director, Economics and Life.

2. Silantyev, N. A., \& Malinovsky, V. R. (1990). Technical regulation of labor in engineering: Textbook. M.: Mechanical Engineering.

3. Scott Sink, D. (1989). Performance Management: Planning, Measurement and Evaluation, Monitoring and Enhancement. (p.528). M.: Progress.

4. Uzdemir, A. P. (1995). Dynamic integer optimization problems in economics. (p.288). M.: Fizmatlit, - (Optimization and operations research).

5. Ehrenberg, R. J., \& Smith, R. S. (1996). Modern labor economics. Theory and public policy. Per. in English. M.: Publishing House of Moscow State University.

6. Fisher, S., Dornbusch, P., \& Schmalenzi, P. Economy. M.: Delo.

7. (1997). Human Resource Management in a Social Market Economy. In R. Marr and G. Schmidt (Eds.). The International Labour Organization. Ed. MSU.

8. (1998). Economics: Principles, problems and policies. Per. from English McConnell KR, Bru
C.JI Turan. Bishhek 1996.152. J. The Economist №7.

9. Taylor, R. (1978). Per. from English Noise. M. Mir.

10. Yakovlev, R. A. (1998). The concept of wage reform. M. Research Institute of Labor.

11. Tursunov, B. (2017). Ways of increasing the efficiency of usage the production capacity of textile enterprises. Byulleten' nauki $i$ praktiki, (8), 232-242.

12. Ortikmirzaevich, T. B. (2017). Principles and functions of management of production capacity. Journal of Process Management. New Technologies, 5(4), 61-68.

13. Tursunov, B. (2017). Features of the method of calculation of production capacities of the textile enterprises. Byulleten' nauki $i$ praktiki, (10), 213-222

14. Babenko, I. V., \& Kojukhova, V. A. (2016). Osnovniye naplavleniya povisheniya effektivnosti truda na predpriyatii. Scientific electronic journal "Koncept", Vol. 9 (september). http://e-koncept.ru/2016/16192.htm 